\title{
УРАХУВАННЯ ФІЗІОЛОГІЧНИХ ТА ПСИХОЛОГІЧНИХ ОСОБЛИВОСТЕЙ ЛЮДИНИ У ПРОЦЕСІ ПРОФЕСІЙНӦ̈ ПІДГОТОВКИ МАЙБУТНІХ ФАХІВЦІВ-МЕДИКІВ
}

\author{
Л. В. Кравчук, С. В. Бондаренко, Н. В. Довбенко \\ ДВНЗ “Тернопільський держсавний медичний університет імені І. Я. Горбачевського МОЗ Украӥни”
}

\section{TAKING INTO ACCOUNT THE PHYSIOLOGICAL AND PSYCHOLOGICAL PECULIARITIES OF A MAN IN THE PROCESS OF PROFESSIONAL TRAINING OF FUTURE SPECIALISTS-PHYSICIANS}

\author{
L. V. Kravchuk, S. V. Bondarenko, N. V. Dovbenko \\ SHEI "Ternopil State Medical University by I. Ya. Horbachevsky of MPH of Ukraine"
}

\begin{abstract}
У статті вказано на значимість розуміння та знання характеру студентів, що сприяс виробленню сприятливої атмосфери “викладач - студент" з метою ефективної підготовки майбутнього фахівця - медика та збереження його здоров'я.

The article adduces the understanding and knowledge of students' character that contributes to the making of beneficial atmosphere "lecturer - student" with the purpose of effective training of the future specialist-physician and his health saving.
\end{abstract}

Вступ. Підготовка фахівців до професійної діяльності в майбутньому розглядається в системі, де існують взаємопов' язаність і взаємозалежність дій складових. Вона базується на науці та накопиченні знань 3 провідного виду діяльності, формуванні професійно грамотності майбутнього спеціаліста [1]. Всі функції людського організму можна звести до трьох основних, таких, як: харчування, рухливість і чутливість. Ці три властивості ніколи не слід випускати з поля зору викладачів у напрямі здоров'язбереження. Перш за все необхідно постійно стежити за правильним харчуванням організму. Шлунок і вся система травлення, серце і вся система кровообігу, легені - ось органи, правильна діяльність яких забезпечує нормальне харчування організму. Тому всі ці органи і їх функції повинні постійно знаходитись під наглядом як молодої людини, так і медицини. Друга основна функція всякого життя є рух, не випадково мудрі говорять: "Рух - життя, спокій смерть". У нашому тілі функції руху виконують ноги, руки, м'язи і тканини опорно-рухового апарату. М'язи, які знаходяться в безпосередньому зв'язку 3 усіма нашими органами, а отже, всі життєві процеси мають рухомий характер. Елементи руху супроводжують процеси харчування, діяльність нервової системи і навіть всіх душевних процесів. Поки триває життя, доти в усіх основних життєвих органах не припиняється рух. Тому необхідно акцентувати увагу студентів на негативних наслідках впливу гіподинамії на здоров'я людини.

Третя основна функція тілесного життя - чутливість. Носієм чутливості є нервова система, завдяки якій наше тіло володіє чутливістю до зовнішніх збудників, або подразників, і здатністю тим чи іншим чином відповідати на збудження. Різноманітність, сила збуджень і реакція формують характер окремої людини. Властивості характеру - активні, спонукаючі сили, які обумовлюють дії і вчинки людини [2]. Тому слід постійно спостерігати, які збудження отримує студент з навколишнього середовища і як він реагує на ці збудження. Як відбувається зіставлення себе зі світом у конкретному часі і просторі, згода чи ні, з конкретними історично-суспільними умовами буття [3], зокрема його “я як вираження особистих дій самоусвідомленості і цілісності” [4]. Молодь несе в собі більше творчих сил, ніж руйнівних, вона скоріше добра, ніж зла, і багато буде залежати від того, наскільки сприятливе середовище, в якому виявиться виховання, тому що і воно буває добре і зле. Тому наступним важливим компонентом $€$ психічне здоров'я, яке значною мірою залежить від створення викладачем позитивних педагогічних умов у навчанні на рівні міжособистісних партнерських взаємодій “викладач - студент".

(ㄱ Л. В. Кравчук, С. В. Бондаренко, Н. В. Довбенко 
Властивості збудження і реакція дають можливість аналізувати стан нервової системи студента на такому рівні, який сприяв би гармонійному розвитку та збереженню його здоров'я.

Основна частина. Важливе значення в системі виховання надається визначенню темпераменту студента, це значною мірою слугуватиме особистим нахилам його і сприятиме вихованню. Загалом тип темпераменту найвиразніше проявляється у поведінці особистості в юності [5]. Творцем вчення про темперамент вважається давньогрецький лікар Гіппократ (4 ст. до н. е.) [6]. Темпераментів дуже багато, їх стільки, скільки і людей. Різниця між ними залежить від клімату і навколишнього природного середовища, від року і віку.

А) Темперамент сангвіністичний походить від того, що в організмі переважає артеріальна кров. Його можна спостерігати за такими зовнішніми ознаками: м'якою, білою, трішки рожевою шкірою з рум'янцем на обличчі, помітною повнотою тіла, міцним і розвинутим пульсом, стрімкими рухами. Душевні риси, які належать цьому темпераменту: жива уява, швидкість розуміння, чутливість неглибока і емоції скороминучі. Люди цього типу не $є$ надто діяльними і схильні дивитись на речі більш з їх світлої сторони, ніж з темної. Цей темперамент більш за все притаманний французам.

Б) Темперамент холеричний - або, іншими словами, жовчний, має такі зовнішні ознаки: шкіра -пружна 3 жовтуватим відтінком, риси обличчя - різкі, будова тіла міцна, розвинута жовчна система, хода тверда і впевнена. Душевні риси: уява-помірна, враження - сильні, умовиводи - швидкі, пристрасті поривчасті, енергія в рішеннях та їх виконання, бадьорість і впевненість у життєвих ситуаціях. Холерик розраховує тільки на свої можливості. Темперамент цей проглядається в більшості політичних діячів, бізнесменів, науковців. А серед сучасних народів цим темпераментом наділені італійці та іспанці.

В) Темперамент меланхолічний походить від того, що в організмі панівне становище займає нервова система і відрізняючими ознаками $є$ : шкіра - ніжна, лице - бліде, задумливе, будова тіла худорлява, м'язи мало розвинуті, рухи плавні, неначе невпевнені. Душевні риси: уява - сильна, розумово здібні, чутливість глибока і в цілому є нахили до сумування i зосередженості, пристрасті-тихі, в праці-постійна старанність. Цей темперамент належить філософам і великим поетам, музикантам, а з європейських народів він найбільш притаманний німцям. Студенти 3 таким темпераментом навчаються 3 задоволенням, і розумові їхні здібності розвиваються рано і швидко.
Г) Перевага в організмі лімфи сприяє утвердженню темпераменту флегматичному. Його зовнішні ознаки: холодна, делікатна шкіра, огрядність тіла при короткій шиї, м'які округлені мускули, разом з тим повільні рухи. Відносно душевних властивостей флегматик відрізняється: в'ялою уявою, слабкою чутливістю і відсутністю сильних пристрастей, зате розум - твердий, багатооб'ємний, а звідси - спокійна душевна рівновага і здатність до серйозної, копіткої праці.

Цей темперамент найбільш зустрічається серед північних народів, а особливо в англійців.

Нормальним темпераментом можна вважати той, при якому діяльність тіла і духовних рис знаходяться в рівновазі. До розвитку такого темпераменту і повинно прагнути виховання.

3 формування темпераментів ми бачимо, що зовнішня природа людини часто вказує на ії здібності і на перевагу в ній тих чи інших духовних рис. Звідси і зрозуміло, чого ми інколи за першим нашим враженням складаємо собі загальне поняття про характер певної людини. Зрозуміло, що особливості будови тіла аж ніяк не можна вважати за еквівалент темпераменту [7]. При будь-якому типі нервової системи, при наявності будь-якого темпераменту можливо виробити, виховати всі суспільні необхідні позитивні риси особистості і поведінки. Люди в багато чому подібні, але й в багато чому відрізняються. В цьому складному лабіринті, іноді хаосі, ми намагаємось знайти порядок і осмислити зв'язки [8].

ФІЗІОНОМІКА - навчає розпізнавати душевні властивості людини за формою іiі тіла і особливо за рисами обличчя, розкриває тенденціїїї особистої природи, вона пропонує їй засоби для вивчення самої себе [9]. Ось для прикладу деякі дані цього напрямку: найбільше духовний розвиток зустрічається в людей середнього росту, при дуже великому рості рідко зустрічаються великі здібності, та при дуже малому рості рідко зустрічається сила волі.

А) Помірна повнота тіла вказує на жвавість природи, легкий і грайливий розум; тучність тіла-в'ялість природи, розум сповільнений, але грунтовний; худорлявість - на сприйняття духовної природи людини.

Б) Міцні, товсті кістки і широкі груди є ознакою рішучості, сили і мужності; тонкі кістки - ознаки слабкої волі, ніжності і жіночого характеру.

В) Прямий стан і пряма шия вказують на бадьорість духу і впевненість у собі; згорблений стан і зігнута шия - на понурість, нерішучість, облесливість; тверда хода, розкачування в сторони - на нетвердість розуму. 
Г) Темне, жорстке, курчаве волосся свідчить про твердість волі, енергію, мужність; світле, м'яке, ніжне волосся означає слабкість, ніжність, чутливість.

Д) Особливо важливе для фізіономіки лице. Чим більше прямий профіль обличчя в людини, тим більше обличчя досконале, тим більше розвинута в ньому духовна діяльність.

Е) Високий лоб і складки чи морщини на ньому означають заклопотаність, сильну діяльність думки; глибокі, криві і косі морщини говорять про твердий i грубий характер.

€) Очі, ніс і вуха - сфера чутливості. Живі і швидкі очі вказують на діяльний характер; опущені вії говорять про задуманість; волов' ячі, сонливі очі - притупленість розуму.

Ж) Ніс великий, зігнутий - сила волі, мужність; тонкий і гострий - означає жвавість розуму, хитрість і глузування; кирпатий ніс - цікавість, сміливість; невеликий ніс підкреслює нерозвиненість і слабкість. Дуже великі вуха - обмеженість і слабкість, невеликі-підкреслюють розум і енергію.

3) Рот, щоки і підборіддя складають сферу чутливості. Змінюючись, рот виражає різні почуття - ве-

\footnotetext{
Лiтература

1. Марушкевич А. Організація навчальної діяльності студентів в сучасних умовах розвитку українського суспільства / А. Марушкевич // Вісник Київського національного університету ім. Тараса Шевченка. -2011. - № 2. - С. 71-74.

2. Норакидзе В. Г. Методы исследования характера личности / В. Г. Норакидзе. - Тбилиси, 1989. - 307 с.

3. Боришевський Й. Психологічні закономірності розвитку духовності особистості / Й. Боришевський. - Київ, 2011. $-197 \mathrm{c}$.

4. Левитов Н. Д. Психология характера / Н. Д. Левитов. М., 1969. -423 c.
}

5. Макарова Л. І. Основи психології і педагогіки / селість, добродушність, ніжність і любов, гнів і злобу; легкі і товсті, розкриті губи означають чутливість і активність; тонкі, тверді, стиснуті губи говорять про сильний характер. Кругле підборіддя підкреслює доброту; довгувате і гостре - хитрість і віроломство.

Краніологія навчає пізнавати властивості характеру людини по випуклості черепа. В словнику ми знаходимо тлумачення даного слова, що краніологія розділ антропології про індивідуальну і групову мінливість черепа людини [10].

Висновок. Отже, із різних спостережень за зовнішніми рисами людини і висновків із них сьогодні складені особливі вчення - фізіономіка, краніологія, вербалістика, які допомагають в освітньо-виховній роботі.

Раніше ці відділи спостереження відігравали важливу роль; сьогодні вони майже втратили значення, але, все-таки, ці найперші спостереження можуть певною мірою допомогти викладачеві сканувати першу інформацію про властивості і риси характеру молоді, що сприятиме поліпшенню самого процесу формування доброзичливої атмосфери, що є основною складовою здоров'язбереження в процесі підготовки майбутніх медичних фахівців.

Л. І. Макарова. -К., 2005. - 111 с.

6. Стреляу Я. Роль темперамента в психологическом развитии / Я. Стреляу. - Москва, 1982. -230 с.

7. Трошкін В. О. Темперамент... Що це? / В. О. Трошкін, Ю. Т. Вілінський. -К., 1996. - 95 с.

8. Лоуренс Первин. Психология личности. Теория исследования / Лоуренс Первин, Оливер Джон.-М., 2000. -606 с.

9. Эжен Ледо. Трактат о человеческой физиономии / Эжен Ледо. - Харьков : Фолио, 1996. -492 с.

10. Литвиненко Н. П. Тлумачний словник медичних термінів / Н. П. Литвиненко, Н. В. Місник. -К. : Ірпінь, 2010. $-847 \mathrm{c}$. 